\title{
SISTEM KENDALI ALAT PEMBERI PAKAN KUCING OTOMATIS MENGGUNAKAN MODUL NODEMCU
}

\author{
Habillah Abbas ${ }^{1}$, Kusnadi $^{2}$, Wanda Ilham ${ }^{3}$, Suhadi Parman ${ }^{4}$ \\ Universitas Catur Insan Cendekia \\ Л. Kesambi 202, Cirebon, Jawa Barat \\ e-mail : abil.abbas17@gmail.com ${ }^{1}$, kusnadi@cic.ac.id ${ }^{2}$, wandailham99@gmail.com ${ }^{3}$, \\ suhadi.parman@cic.ac.id ${ }^{4}$
}

\begin{abstract}
ABSTRAK
Untuk memberikan makan kucing agar optimal maka dibuatnya sistem kendali alat pemberi pakan kucing otomatis menggunakan modul nodeMCU agar dapat mempermudah pemilik kucing yang merasa kesulitan dalam proses pemberian pakan pada kucing. Alat ini dapat bekerja secara otomatis menggunakan modul real time clock (RTC) untuk pengaturan waktu pemberian pakan yang akan dikontrol oleh modul nodemcu sebagai microcontroller dan juga dapat di kontrol langsung melalui smartphone pengguna ketika akan menambahkan pakannya. Alat ini juga dapat mengirim pesan ke smartphone pengguna jika pakan yang berada pada wadah pakan sudah dimakan oleh kucingnya.

Kata Kunci : Pemberi Pakan Kucing Otomatis, Modul NodeMCU, Real Time Clock (RTC), Motor Servo, Sensor Ultrasonik.

ABSTRACT

To feed cats optimally, an automatic cat feeder control system was created using the nodeMCU module in order to make it easier for cat owners who find it difficult to feed cats. This tool can work automatically using a real time clock (RTC) module for setting the feeding time which will be controlled by the nodemcu module as a microcontroller and can also be controlled directly via the user's smartphone when adding feed. This tool can also send messages to the user's smartphone if the feed in the feed container has been eaten by the cat..
\end{abstract}

Keywords: Automatic Cat Feeder, NodeMCU Module, Real Time Clock (RTC), Servo Motor, Ultrasonic Sensor.

\section{PENDAHULUAN}

Memelihara kucing merupakan salah satu hobi yang menyenangkan di kalangan masyarakat, karena kucing adalah salah hewan yang lucu dan dekat dengan manusia, selain itu kucing juga mampu mengurangi stres dan rasa cemas. Akan tetapi memelihara kucing dirumah membutuhkan banyak waktu dan tenaga. Bagi orang-orang yang memiliki kesibukan yang sangat padat tentunya kegiatan memelihara kucing ini akan sangat susah dilakukan. Dalam memelihara kucing, pemberian makan merupakan salah satu hal yang sangat penting, hal ini dikarenakan bahwa tumbuh kembang kucing dipengaruhi oleh nutrisi pada makanan yang diberikan. Selain kandungan nutrisi pada makanan, pemberian makan kucing yang rutin dan teratur serta pemberian porsi yang sesuai juga diperlukan untuk menjaga keseimbangan nutrisi pada kucing agar tetap seimbang, sehingga kucing tetap sehat dan terhindar dari penyakit.

Memiliki hewan peliharaan tentunya membutuhkan waktu dan tenaga untuk merawatnya. Bagi pemelihara kucing yang memiliki aktivitas padat di luar rumah, cukup sulit untuk memberi makan kucing agar tetap rutin dan teratur. Begitu juga ketika pemelihara kucing harus meninggalkan rumah dalam jangka waktu yang lama sehingga harus meninggalkan kucingnya dirumah tanpa bisa memberi makan hingga beberapa hari. Menitipkan kucing pada penitipan hewan menjadi salah satu solusi, hal ini tentunya memerlukan biaya yang cukup besar. dan hanya saja cara ini tentunya tidak praktis ketika pemelihara kucing hanya pergi selama beberapa jam. Dari beberapa masalah diatas maka dibutuhkan sebuah alat dengan sistem otomatis pemberi pakan. Dengan sedikit sentuhan mekanik akan lebih menyederhanakan perancangan alat otomatis ini serta bantuan nodeMCU yang memproses Real Time Clock (RTC) untuk mempermudah mengatur jadwal pemberian makan pada kucing. 


\subsection{Identifkasi Masalah}

Berdasarkan latar belakang masalah diatas, maka penulis menguraikan identifikasi permasalahan sebagai berikut :

1. Bagaimana cara membuat alat yang dapat memberikan makan kucing sesuai dengan jadwal yang diberikan menggunakan modul Real Time Clock (RTC)?

2. Bagaimana cara membuat alat pemberi pakan kucing otomatis yang dapat dikendalikan dari jarak jauh kapanpun dan dimanapun?

3. Bagaimana cara menghubungkan telegram dengan alat pemberi makan kucing otomatis?

\subsection{Batasan Masalah}

Penulis membatasi permasalahan dalam penulisan ini agar pembahasan tidak menyimpang dari tujuan, maka dilakukan pembatasan masalah sebagai berikut :

1. Penelitian ini tidak membahas tentang pemberian minum pada kucing.

2. Apabila pakan pada penampung sudah habis, maka harus diisi secara manual oleh manusia.

3. Alat ini hanya digunakan pada kucing peliharaan.

4. Pakan kucing yang digunakan adalah jenis dry food (sereal) untuk kucing.

5. Alat ini harus terkoneksi oleh internet.

\subsection{Tujuan Penelitian}

Berdasarkan permasalahan diatas maka tujuan dari pembuatan penelitian ini adalah :

1. Merancang dan membangun sistem kendali pemberian pakan kucing yang menggunakan atau mengintegritaskan antara sensor, motor dan timer dalam suatu rangkaian mekantronika pada alat pemberian pakan kucing.

2. Dengan dibuatnya sistem kendali alat pemberi pakan kucing ini maka dapat digunakan sebagai solusi untuk para pemilik kucing ketika sedang tidak berada dirumah atau sedang diluar rumah, sehingga pemilik kucing dapat memberikan pakan kepada kucingnya dimana saja dan kapan saja.

\section{KAJIAN PUSTAKA}

\subsection{Pakan Kucing}

Kucing mempunyai pola dan perilaku makan yang sangat spesifik. Kucing makan sekitar 3-4 kali sehari, dengan total waktu makan sekitar 30 menit perhari. Kucing hanya makan beberapa gram makanan setiap kali makan [1]. Indera pengecap menjadi sangat penting dan merupakan mekanisme hewan memilih pakan untuk memenuhi kebutuhan hidupnya. Penelitian Hewson-Hughes et al memberikan gambaran yang sangat jelas mengenai kebutuhan nutrisi kucing, khususnya protein, lemak dan karbohidrat. Dalam sehari seekor kucing membutuhkan sekitar 26 gram protein, 9 gram lemak dan 8 gram karbohidrat yang mana unsur tersebut setara dengan kebutuhan kalori sebanyak 52\% dari protein, 36\% dari lemak dan $12 \%$ dari karbohidrat. Beberapa penelitian juga menuturkan bahwa seekor kucing yang hidup di dalam rumah hanya menghabiskan sedikit energy. Kucing dengan berat badan $\pm 3.5 \mathrm{~kg}$, hanya memerlukan asupan normal sekitar 50 gram makanan kering perharinya [2].

\subsection{Internet of Things (IoT)}

Perkembangan teknologi semakin pesat dari waktu ke waktu. Dulu, mungkin kita hanya bisa berimajinasi atau menonton film-film fiksi sains soal teknologi canggih. Kini, berbagai peralatan/mesin sudah dilengkapi dengan kecanggihan teknologi yang bisa memudahkan pekerjaan kita sehari-hari. Mulai dari mobil pintar (smart car) yang bisa jalan sendiri ke berbagai tujuan tanpa pengemudi manusia, hingga mesin pintar semacam Alexa yang bisa bersuara mengingatkan Anda untuk melakukan ini-itu sesuai jadwal. Seluruh teknologi terbaru ini adalah bagian dari Internet of Things.

\subsection{Mikrokontroler}

Mikrokontroler adalah sistem komputer yang dikemas dalam sebuah Integrated Circuit (IC). Dimana didalam IC terdapat komponen-komponen penting yang ada pada komputer pada umumnya seperti komputer Central Processing Unit (CPU), RAM, ROM, Port IO. Berbeda dengan PC yang umumnya dirancang untuk digunakan secara umum, mikrokontroler sendiri biasanya dirancang hanya untuk mengerjakan tugas atau fungsi yang khusus saja (special purpose) yaitu mengontrol sistem tertentu. 


\subsection{Modul Wifi NodeMCU}

NodeMCU adalah sebuah board elektronik yang berbasis chip ESP8266 dengan kemampuan menjalankan fungsi mikrokontroler dan juga koneksi internet ( $\mathrm{WiFi}$ ). Terdapat beberapa pin I/O sehingga dapat dikembangkan menjadi sebuah aplikasi monitoring maupun controlling pada proyek IoT. NodeMCU ESP8266 dapat diprogram dengan compiler-nya Arduino, menggunakan Arduino IDE. Bentuk fisik dari NodeMCU ESP 8266, terdapat port USB (mini USB) sehingga akan memudahkan dalam pemrogramannya.[13].

\subsection{Motor Servo}

Servo atau motor servo merupakan sebuah komponen elektronika yang dirancang dari beberapa perangkat terdari dari serangkaian gear, rangkaian kontrol dan potensiometer. Motor servo dapat di set-up atau diatur untuk menentukan dan memastikan poros keluaran motor pada posisi sudut. Dari perangkatperangkat yang berada di dalam motor servo memiliki fungsi dan tugas masing-masing. Seperti potensiometer atau variabel resistor mempunyai fungsi menentukan batasan maksimum putaran sumbu motor servo.

\subsection{Sensor Jarak (Ultrasonic)}

Sensor jarak (Ultrasonic) merupakan gelombang yang umum digunakan untuk radar untuk mendeteksi keberadaan suatu benda dengan memperkirakan jarak antara sensor dan benda tersebut. sensor jarak yang umum digunakan dalam penggunaan untuk mendeteksi jarak yaitu sensor ultrasonik. pengertian sensor ultrasonik adalah sebuah sensor yang berfungsi untuk mengubah besaran fisis (bunyi) menjadi besaran listrik dan sebaliknya.

\subsection{Real Time Clock (RTC)}

RTC (Real time clock) adalah jam elektronik berupa chip yang dapat menghitung waktu (mulai detik hingga tahun) dengan akurat dan menjaga atau menyimpan data waktu tersebut secara real time. Karena jam tersebut bekerja real time, maka setelah proses hitung waktu dilakukan output datanya langsung disimpan atau dikirim ke device lain melalui sistem antarmuka.

\section{ANALISIS DAN PERANCANGAN SISTEM}

\subsection{Diagram Blok Sistem}

Diagram blok sistem merupakan salah satu bagian terpenting dalam perancangan peralatan elektronik, karena dalam diagram blok dapat diketahui prinsip kerja secara keseluruan dari rangkaian elektronik yang dibuat. Sehingga keseluruan blok dari alat yang dibuat dapat membentuk suatu sistem yang dapat difungsikan atau sistem yang bekerja sesuai dengan perancangan.

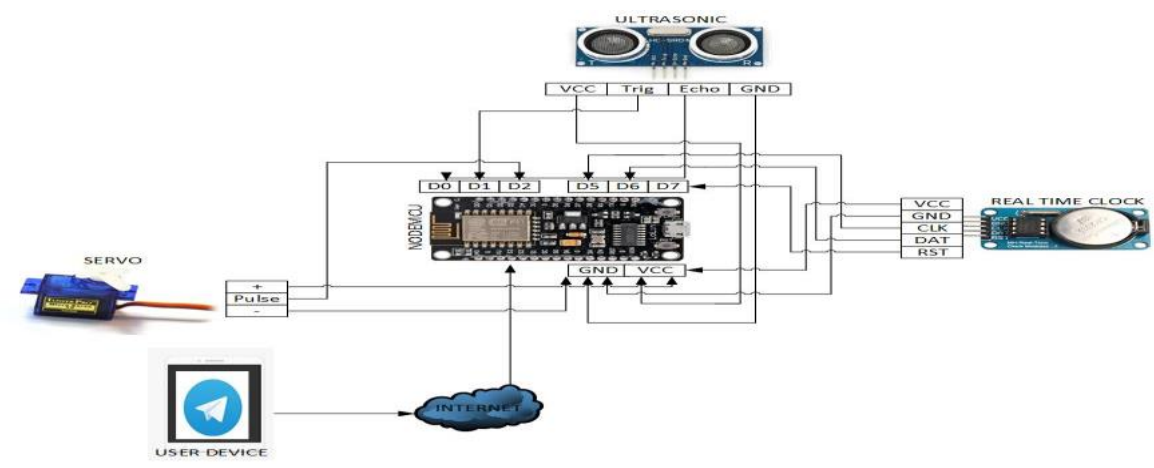

Gambar 1. Blok Diagram Sistem 
3.2. Perancangan Hardware

3.2.1. Perancangan Real Time Clock (RTC)

Perancangan Real Time Clock (RTC) digunakan untuk mengatur penjadwalan pemberian pakan secara otomatis.

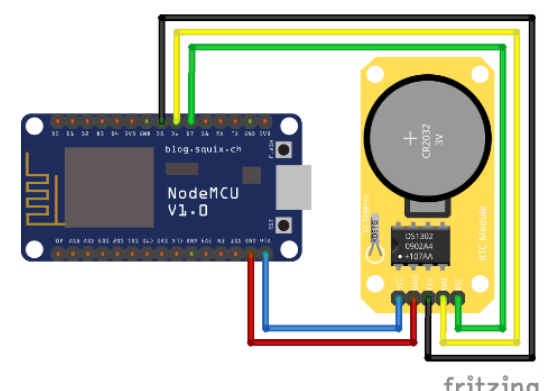

Gambar 2. Perancangan Rangkaian RTC

\subsubsection{Perancangan Sensor Ultrasonic}

Perancangan Sensor Ultrasonic digunakan untuk mengetahui jumlah yang ada pada wadah pakan kucing.

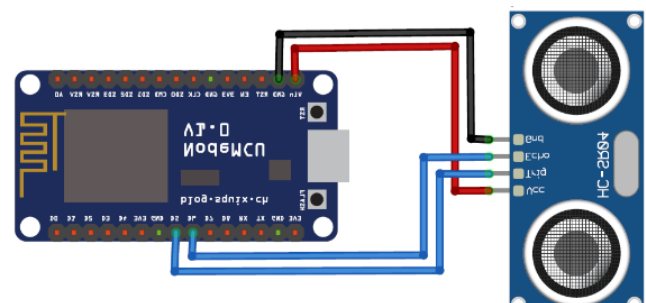

Gambar 3. Perancangan Rangkaian Sensor Ultrasonic

\subsubsection{Perancangan Motor Servo}

Perancngan Motor Servo digunakan untuk membuka tutup pintu penampung pakan sesuai dengan apa yang telah di program.

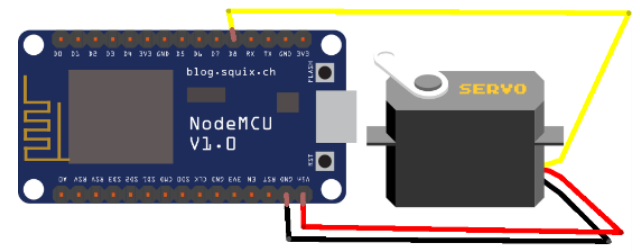

Gambar 4. Perancangan Rangkaian Motor Servo

\subsubsection{Perancangan Rangkaian Sistem Keseluruhan}

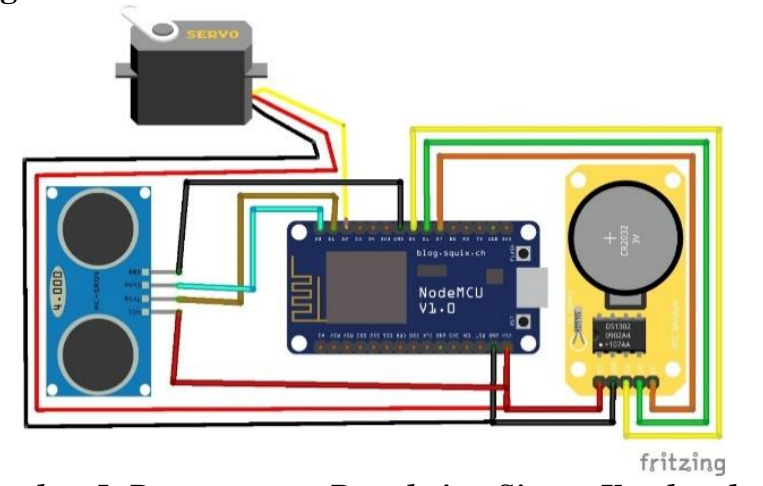

Gambar 5. Perancangan Rangkaian Sistem Keseluruhan

Berdasarkan gambar 5. Alat ini mengulas tentang bagaimana melakukan pemberian pakan dengan NodeMCU sebagai mikrokontroler yang menggerakkan seluruh komponen dalam alat ini. Sensor ultrasonic membaca jarak pakan yang ada diwadah pakan kucing, Motor servo akan membuka wadah penampung 
pakan sesuai dengan jadwal pakan yang telah diprogram sebelumnya melalui Real Time Clock (RTC), lalu data bahwa pakan telah diberikan akan terkirim ke telegram user melalui nodeMCU.

Dari rangkaian sistem di atas menggambarkan cara kerja komunikasi antar perangkat dalam mengendalikan perangkat dengan penjelasan berikut :

1. Koneksi NodeMCU dengan Real Time Clock (RTC)

Tabel 1. Koneksi NodeMCU dengan Real Time Clock (RTC)

\begin{tabular}{|c|c|l|}
\hline NodeMCU & Real Time Clock & \multicolumn{1}{c|}{ Keterangan } \\
\hline Pin D5 & RST & Pin untuk Serial Riset pin \\
\hline Pin D6 & CLK & Pin untuk Serial Clock pin \\
\hline Pin D7 & DAT & Pin untuk Serial Data pin \\
\hline GND & GND & Pin untuk sumber daya arus negatif \\
\hline Vin & VCC & Pin untuk sumber daya arus positif \\
\hline Pin D5 & RST & Pin untuk Serial Riset pin \\
\hline
\end{tabular}

2. Koneksi NodeMCU dengan Sensor Ultrasonic

Tabel 2. Koneksi NodeMCU dengan Sensor Ultrasonic

\begin{tabular}{|c|c|l|}
\hline NodeMCU & Sensor Ultrasonic & \multicolumn{1}{c|}{ Keterangan } \\
\hline Pin D1 & Trig & Pin untuk membangkitkan sinyal \\
\hline Pin D0 & Echo & Pin untuk mendeteksi sinyal pantulan \\
\hline GND & GND & Pin untuk sumber daya arus negatif \\
\hline Vin & VCC & Pin untuk sumber daya arus positif \\
\hline
\end{tabular}

3. Koneksi NodeMCU dengan Motor Servo

Tabel 3. Koneksi NodeMCU dengan Motor Servo

\begin{tabular}{|c|c|c|}
\hline NodeMCU & Motor Servo & Keterangan \\
\hline Pin D2 & Data & Pin untuk mendapatkan data \\
\hline GND & GND & Pin untuk sumber daya arus negatif \\
\hline Vin & $+5 \mathrm{Vdc}$ & Pin untuk sumber daya arus positif \\
\hline
\end{tabular}

\subsubsection{Skematik Diagram}

政

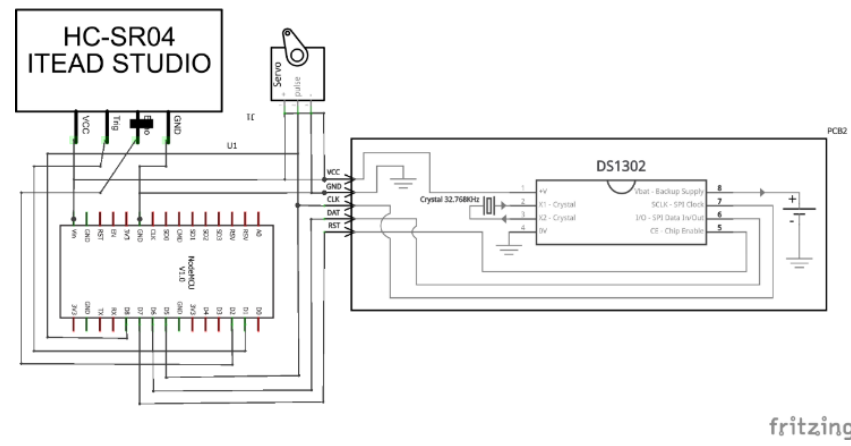

Gambar 6. Skematik Diagram

Keterangan dari gambar 6. Skematik Diagram :

1. Pada node MCU pin VCC dihubungkan dengan jalur output VCC pada rangkaian Power Supply. 
2. Pada node MCU pin GND (Ground) dihubungkan dengan jalur GND pada rangkaian Power Supply, juga dihubungkan pada seluruh pin komponen yang bertipe netral atau GND.

3. Pada Ultrasonic pin VCC dihubungkan ke pin VCC, pin GND pada pin GND, pin Trig pada pin D1 dan Echo pada D0.

4. Pada motor servo pin VCC dihubungkan ke pin VCC, pin GND pada pin GND, dan pin pulse pada pin D8 sebagai pin digital.

5. Pada pin header RTC yang akan diletakkan modul RTC, pin VCC akan dihubungkan ke pin VCC pada node MCU, pin GND akan dihubungkan ke pin GND, pin CLK akan dihubungkan ke pin D5 pada node MCU sebagai pin digital, pin DAT dihubungkan ke pin D6 pada pin node MCU sebagai pin digital dan pin RST dihubungkan ke pin D7 pada node MCU sebagai pin digital.

\subsubsection{Flowchart Sistem Otomatis Pemberian Pakan}

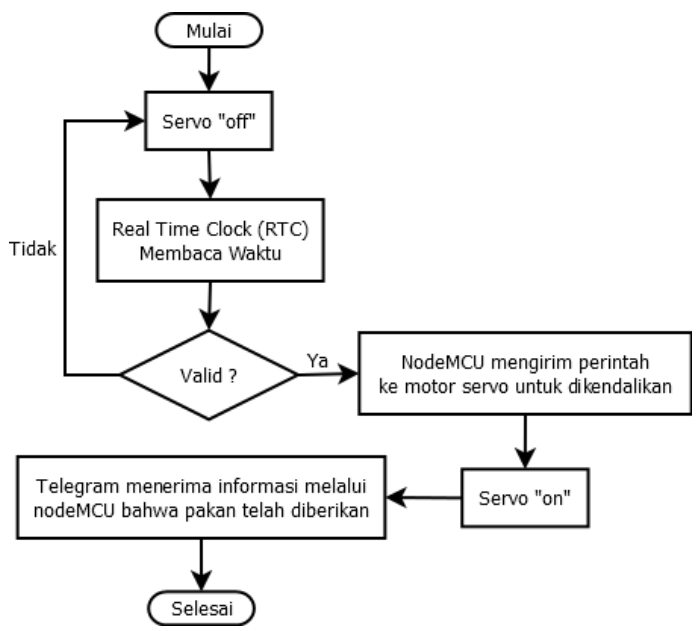

Gambar 7. Flowchart Sistem Otomatis Pemberian Pakan

Diagram alir yang pada Gambar 7. menunjukan cara kerja sistem monitoring pemberi pakan otomatis dimana posisi awal yaitu motor servo dalam keadaan mati, Kemudian Real Time Clock (RTC) melakukan validasi waktu dengan ketentuan jika waktu telah sesuai dengan apa yg telah di tentukan, maka motor servo akan menerima perintah dari NodeMCU untuk bergerak dan telegram akan mengirim pesan informasi kepada user melalui NodeMCU bahwa pakan telah keluar.

\subsubsection{Flowchart Sistem Kendali Pemberian Pakan}

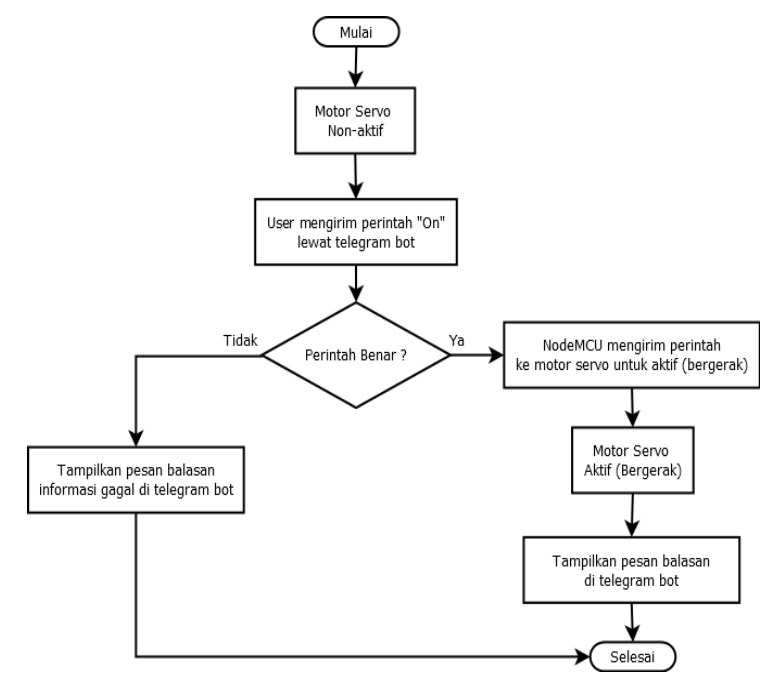

Gambar 8. Flowchart Sistem Kendali Pemberian Pakan 
Diagram alir yang ditunjukkan pada Gambar 8. menunjukan cara kerja sistem kendali pada proses pemberian pakan dengan posisi awal motor servo mati. Kemudian user mengirimkan perintah dengan cara mengetik "On" pada telegram bot. Kemudian telegram akan mengirim pesan bahwa pakan telah diberikan melalui NoceMCU.

\section{IMPLEMENTASI DAN PENGUJUAN}

\subsection{Implemantasi}

Tahap implementasi ini merupakan tahap akhir dari serangkaian sistem yang telah di analisis dan di rancang pada tahapan analisis dan perancangan sistem. Pada implementasi ini dilakukan tahap - tahap yang meliputi langkah - langkah instalasi aplikasi Arduino IDE pada PC, instalasi telegram bot pada smartphone, serta penulisan kode program.

\subsubsection{Kebutuhan Sistem}

Di dalam implementasi dan pengujian sistem yang dibangun ini memerlukan beberapa kebutuhan, baik dari software maupun hardware beserta spesifikasinya, serta memerlukan langkah - langkah instalasi maupun konfigurasi.

\section{A. Kebutuhan Hardware}

1. Komputer

Spesifikasi komputer yang digunakan pada pembuatan sistem ini adalah sebagai berikut :

Tabel 4. Spesifikasi Komputer

\begin{tabular}{|c|l|l|}
\hline No. & \multicolumn{1}{|c|}{ Komponen } & \multicolumn{1}{c|}{ Keterangan } \\
\hline 1. & Sistem Operasi & Windows 10 (64-bit) \\
\hline 2. & RAM & $4 \mathrm{gb}$ \\
\hline 3. & VGA & Intel HD Graphics \\
\hline 4. & Memor VGA & $128 \mathrm{MB}$ \\
\hline 5. & Processor & Intel Celeron Processor B815 $1.60 \mathrm{GHz}$ \\
\hline
\end{tabular}

\section{NodeMCU}

Modul NodeMCU akan menerima dan mengirimkan perintah terhadap motor servo, sensor ultrasonic serta RTC. Adapun spesifikasi NodeMCU yang digunakan pada sistem ini adalah sebagai berikut :

Tabel 5. Spesifikasi NodeMCU

\begin{tabular}{|c|l|l|}
\hline No. & \multicolumn{1}{|c|}{ Komponen } & \multicolumn{1}{c|}{ Keterangan } \\
\hline 1. & Mikrokontroller & ESP8266 \\
\hline 2. & Kanal PWM & $10 \mathrm{Kanal}$ \\
\hline 3. & GPIO Pin & 13 Pin \\
\hline 4. & Flash Memory & $4 \mathrm{MB}$ \\
\hline 5. & Input Tegangan & $3.3 \mathrm{~V} \sim 5 \mathrm{~V}$ \\
\hline 6. & Clock Speed & $40 / 26 / 24 \mathrm{MHz}$ \\
\hline 7. & Wifi & IEEE $802.11 \mathrm{~b} / \mathrm{g} / \mathrm{n}$ \\
\hline 8. & Frekuensi & $2.4 \mathrm{GHz}-22.5 \mathrm{Ghz}$ \\
\hline 9. & USB Port & Micro USB \\
\hline 10. & USB Chip & $\mathrm{CH} 340 \mathrm{G}$ \\
\hline
\end{tabular}

3. Motor Servo

Motor servo ini dikendalikan dengan mikrokontroller NodeMCU makan akan membuka pintu katup yang ada pada wadah penampung untuk mengeluarkan pakan ke wadah pakan kucing. Adapun spesifikasi dari modul motor servo yang digunakan ialah sebagai berikut : 
Tabel 6. Spesifikasi Motor Servo

\begin{tabular}{|c|l|l|}
\hline No. & \multicolumn{1}{|c|}{ Komponen } & \multicolumn{1}{c|}{ Keterangan } \\
\hline 1. & Lebar & $13.4 \mathrm{~g}$ \\
\hline 2. & Dimensi & $22.5 \times 12 \times 35.5 \mathrm{~mm}$ approx \\
\hline 3. & Torsi awal & $1.8 \mathrm{kgf} \mathrm{cm}(4.8 \mathrm{~V}), 2.2 \mathrm{kgf} \mathrm{cm}(6 \mathrm{~V})$ \\
\hline 4. & Kecepatan & $0.1 \mathrm{~s} / 60 \mathrm{suhu}(4.8), 0.00 \mathrm{~s} / 60 \mathrm{suhu}(6 \mathrm{~V})$ \\
\hline 5. & Tegangan & $4,8 \mathrm{~V}-6.0 \mathrm{~V}$ \\
\hline
\end{tabular}

4. Sensor Ultrasonic

Sensor Ultrasonic dihubungkan dengan mikrokontroller NodeMCU yang berfungsi untuk mendeteksi jumlah pakan pada wadah pakan apakah masih ada atau tidak. Adapun spesifikasi dari Sensor Ultrasonic yang digunakan ialah sebagai berikut :

Tabel 7. Spesifikasi Sensor Ultrasonic

\begin{tabular}{|c|l|l|}
\hline No. & \multicolumn{1}{|c|}{ Komponen } & \multicolumn{1}{c|}{ Keterangan } \\
\hline 1. & Jangkauan deteksi & $2 \mathrm{~cm}-500 \mathrm{~cm}$ \\
\hline 2. & Tegangan kerja & $5 \mathrm{~V} \mathrm{DC}$ \\
\hline 3. & Resolusi & $1 \mathrm{~cm}$ \\
\hline 4. & Frekuensi ultrasonik & $40 \mathrm{kHz}$ \\
\hline
\end{tabular}

5. Real Time Clock (RTC)

Modul RTC ini berfungsi untuk pengaturan jadwal pemberian pakan secara otomatis yang dihubungkan langsung dengan mikrokontroller NodeMCU. Adapun spesifikasi dari Sensor Ultrasonic yang digunakan ialah sebagai berikut :

Tabel 8. Spesifikasi Real Time Clock (RTC)

\begin{tabular}{|c|l|l|}
\hline No. & \multicolumn{1}{|c|}{ Komponen } & \multicolumn{1}{c|}{ Keterangan } \\
\hline 1. & Komunikasi & I2C (Serial data \& clock) \\
\hline 2. & Include battery & $3 \mathrm{~V}$ \\
\hline 3. & Dimensi & $44 \times 23 \times 16 \mathrm{~mm}$ \\
\hline 4. & Tegangan & $3,3-5,5 \mathrm{~V}$ \\
\hline
\end{tabular}

\section{B. Kebutuhan Software}

Berikut ini adalah beberapa kebutuhan perangkat lunak yang dibutuhkan dalam pembuatan pada sistem ini :

Tabel 9. Kebutuhan Software

\begin{tabular}{|c|l|l|}
\hline No. & \multicolumn{1}{|c|}{ Komponen } & \multicolumn{1}{c|}{ Keterangan } \\
\hline 1. & DIA & Untuk membuat perancangan sistem \\
\hline 2. & Arduino IDE 1.8 .13 & Untuk memprogram sistem \\
\hline 3. & Telegram & Untuk sistem pengendalian dan informasi \\
\hline 4. & Fritzing 0.8 & Untuk membuat perancangan interkoneksi \\
\hline
\end{tabular}




\subsection{Hasil Pengujian}

\subsubsection{Pengujian NodeMCU}

Pengujian ini dilakukan apakah nodeMCU dapat terhubung dengan wifi atau tidak.

A. Peralatan Yang Digunakan

1. NodeMCU esp8266

2. Kabel data

3. Koneksi wifi

4. Arduino IDE

B. Langkah Pengujian

1. Hubungkan kabel data dari nodeMCU ke port laptop.

2. Buka program Arduino IDE dan buka kodingan nodeMCU.

3. Ganti ssid dan password sesuai dengan yang kita gunakan.

4. Upload dan tunggu sampai proses selesai.

C. Hasil Pengujian

Dari hasil pengujian nodeMCU dapat disimpulkan bahwa ketika kita mengubah ssid sesuai dengan yang kita gunakan, maka nodeMCU dapat terhubung langsung dengan wifi.

\subsubsection{Pengujian Real Time Clock (RTC)}

Pada pengujian Real Time Clock (RTC) ini bertujuan untuk menyesuaikan waktu pada modul

RTC dengan jam yang ada dilaptop.

A. Peralatan Yang Digunakan

1. Modul RTC

2. NodeMCU

3. Kabel Jumper

4. Laptop

5. Arduino IDE

B. Langkah Pengujian

1. Hubungkan CLK, DAT, RST ke pin D5, D6, D7 pada nodeMCU menggunakan kabel jumper

2. Hubungkan GND ke GND, dan VCC ke VIN nodeMCU.

C. Hasil Pengujian

Dari hasil pengujian yang dilakukan maka dapat disimpulkan bahwa nodeMCU dapat menampilkan data yang berasal dari Real Time Clock (RTC).

\subsubsection{Pengujian Motor Servo}

Pengujian motor servo ini dilakukan untuk mengetahui apakah motor servo dapat bergerak membuka dan menutup wadah pakan sesuai dengan perintah nodeMCU.

A. Peralatan Yang Digunakan

1. Motor Servo

2. NodeMCU

3. Kabel Jumper

4. Arduino IDE

B. Langkah Pengujian

1. Hubungkan kabel servo yang warna kuning sebagai data ke D2 pada nodeMCU.

2. Hubungkan kabel warna merah sebagai VCC ke pin VCC pada nodeMCU.

3. Hubungkan kabel warna coklat sebagai GND ke pin GND pada nodeMCU.

C. Hasil Pengujian

Pada pengujian motor servo kali ini dapat berjalan sesuai dengan program yang telah ditentukan.

\subsubsection{Pengujian Sensor Ultrasonic}

Pengujian sensor ultrasonic ini dilakukan untuk menentukan jarak pada tempat pakan kucing apakah pakanan tersebut sudah dimakan oleh kucingnya atau belum.

A. Peralatan Yang Digunakan

1. Sensor Ultrasonic

2. NodeMCU 
3. Kabel Jumper

4. Arduino IDE

B. Langkah Pengujian

1. Hubungkan pin trigger ke pin D1, dan pin Echo ke pin D0.

2. Hubungkan pin GND dengan pin GND, dan pin VCC dengan pin VCC pada nodeMCU dengan menggunakan kabel jumper.

C. Hasil Pengujian

Pada pengujian sensor ultrasonic ini bekerja dengan baik dan sesuai dengan apa yang telah diprogram.

\subsubsection{Sistem Kendali Melalui Telegram Bot}

A. Mengirim Perintah "On"

Pada dinding pesan Bot di Telegram, sudah terkirim perintah “On” yang dimana pakan akan keluar dengan sendirinya dan kemudian bot akan mengirim informasi bahwa pakan sudah diberikan.

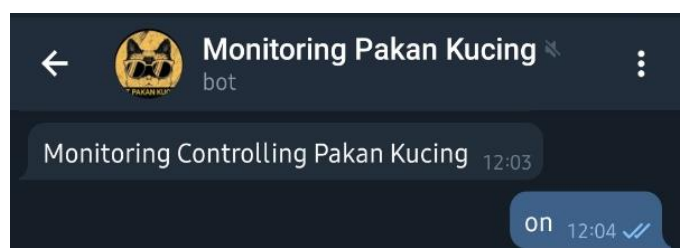

Gambar 9. Perintah “On” Pada Telegram Bot

B. Menerima Informasi Bahwa Pakan Sudah Diberikan

Jika pakan telah diberikan, maka informasi pakan sudah diberikan akan dikirim dari NodeMCU melalui telegram bot.

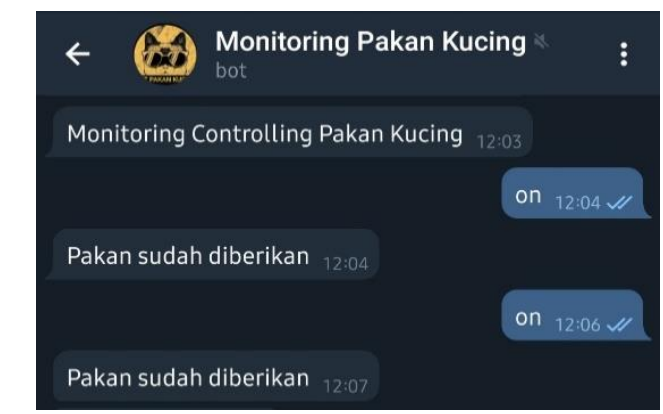

Gambar 10. Informasi Pakan Sudah Diberikan

C. Menerima Informasi Bahwa Pakan Sudah Dimakan Kucing

Dibagian kali ini jika makanan tersebut telah dimakan oleh kucing dan kemudian volume makanan itu berkurang, maka informasi tersebut akan dikirim ke telegram melalui NodeMCU.

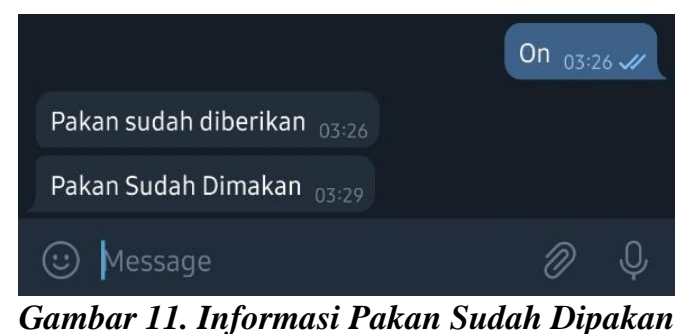

\subsubsection{Sistem Otomatis Pemberian Pakan Kucing}

Dalam sistem otomatis ini dikontrol oleh modul Real Time Clock (RTC) yang dimana jika waktu telah sesuai dengan jadwal yang telah diprogram sebelumnya, motor servo akan otomatis membuka pintu agar pakan tersebut keluar dari wadah penampungnya. 


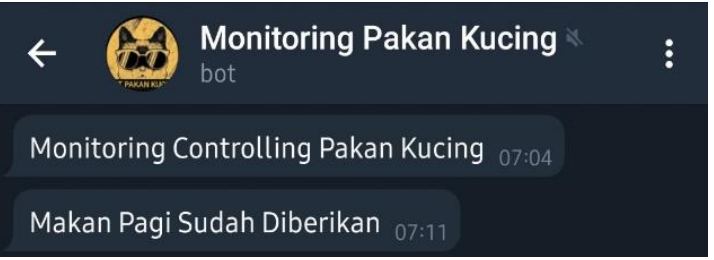

Gambar 12. Informasi Makan Pagi Sudah Kluar Otomatis

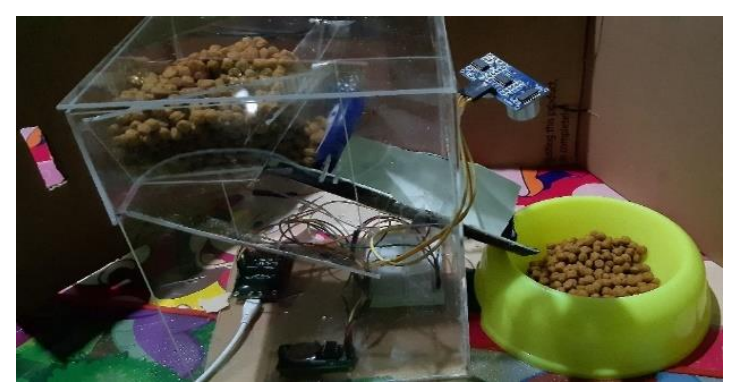

Gambar 13. Informasi Pakan Keluar Dengan Otomatis

\section{KESIMPULAN}

\subsection{Kesimpulan}

Setelah melewati tahap perancangan dan pengujian alat, maka didapatkan beberapa kesimpulan sebagai berikut :

1. Real Time Clock (RTC) yang mampu menginput waktu makan kucing sehingga kucing dapat makan tepat waktu.

2. Sistem pemberi pakan kucing yang dibuat mampu berfungsi dengan baik menggunakan sistem kendali yang telah dibuat. Fitur penjadwalan pemberian makan pada alat ini dapat berjalan dengan baik. Alat pemberi pakan kucing dengan sistem kendali dapat digunakan sebagai alat bantu dalam memelihara kucing sehingga dapat menekan angka kematian kucing akibat kurang terawat serta stres karena kurangnya makanan.

3. Cepat lambatnya pengiriman notifikasi telegram dipengaruhi oleh kecepatan internet.

\subsection{Saran}

Pada penelitian ini tidak lepas dari berbagai macam kekurangan dan kesalahan baik dari perancangan sistem maupun peralatan yang telah penulis buat maka dari itu agar sistem dapat dikembangkan lebih sempurna, saran dari penulis antara lain sebagai berikut :

1. Pada alat ini masih terdapat kekurangan pada sumber daya arus listrik. Diharapkan dapat dikembangkan lagi dengan baterai untuk menghindari apabila terjadi pemadaman listrik, sehingga alat dapat bekerja maksimal meskipun terjadi pemadaman listrik.

2. Masih terdapat kekurangan pada motor servo yang digunakan, maka diharapkan kepada penelitian berikutnya untuk mencari jenis motor servo lain yang dapat menutupi

3. Dari tampilan sistem kendali pada telegram masih sangat sederhana, diharapkan kepada pemelitian berikutnya untuk pembaharuan software sistem kendali yang lebih elegan.

4. Diperlukan adanya modifikasi lanjutan agar sistem kendali dapat menjadi lebih mudah dan dapat dioperasikan oleh pengguna awam sekalipun. 


\section{DAFTAR PUSTAKA}

[1] M. I. Saputro and A. Rivaldi, “Alat Pemberi Makan Hewan Peliharaan Otomatis Berbasis Teknologi Internet Of Things ( IoT )," vol. 6, no. 1, pp. 62-71, 2020.

[2] H. Himawan, J. T. Informatika, and F. T. Industri, "Pengembangan alat pemberi makan ikan otomatis menggunakan arduino terintegrasi berbasis iot," vol. 15, no. 02, pp. 87-98, 2018.

[3] N. Adiprasetyo, F. Teknik, and U. M. Malang, "Alat Pemberi Makan Kucing Otomatis Berbasis Arduino Uno," 2017.

[4] S. Winardi, "Rancang Bangun Sistem Pengaman Pintu Rumah Menggunakan Android Berbasis Arduino Uno," e-NARODROID, vol. 2, no. 1, pp. 89-92, 2016, doi: 10.31090/narodroid.v2i1.104.

[5] K. Abdul and K. Wiajaya, "Monitoring Sisa Pakan Kucing Berbasis Internet of Things ( Iot )," 2019.

[6] I. N. Claudiyana Fitriah, Dedi Triyanto, "Sistem Pemberian Pakan Kucing Otomatis Berbasis Arduino Dengan Metode K-Nearest Neighbor (Knn) Dan Antar Muka Berbasis Web," Coding Sist. Komput. Untan, vol. 05, no. 2, pp. 36-46, 2017.

[7] R. Chen, W. Zhai, and Y. Qi, "Mechanism and technique of friction control by applying electric voltage. (II) Effects of applied voltage on friction," Mocaxue Xuebao/Tribology, vol. 16, no. 3, pp. 235-238, 1996.

[8] Y. Efendi, "Internet Of Things (Iot) Sistem Pengendalian Lampu Menggunakan Raspberry Pi Berbasis Mobile,” J. Ilm. Ilmu Komput., vol. 4, no. 2, pp. 21-27, 2018, doi: 10.35329/jiik.v4i2.41.

[9] B. Bin Dahlan, "Sistem Kontrol Penerangan Menggunakan Arduino Uno Pada Universitas Ichsan Gorontalo,” Ilk. J. Ilm., vol. 9, no. 3, pp. 282-289, 2017, doi: 10.33096/ilkom.v9i3.158.282-289.

[10] Z. Zulkarnain, A. Andriana, and A. Rosyada, "Pembuatan Prototipe Alat Pemberi Pakan Kucing Otomatis Berbasis Arduino Nano Dan Terintegrasi Dengan Handphone Via SMS,” J. TIARSIE, vol. 16, no. 2, p. 59, 2019, doi: 10.32816/tiarsie.v16i2.58.

[11] S. A. Putra, "Monitoring Pemberi Pakan Ikan Otomatis," vol. 5068, pp. 35-42, 2019.

[12] K. Y. Triastuti et al., "Monitoring Kondisi Kesehatan Pada Hewan," no. Ciastech, pp. 293-300, 2019.

[13] U. Khair et al., "Alat pemberi makan kucing otomatis berbasis arduino uno pada pet shop,” pp. 9-14.

[14] E. Safrianti, Y. S. Tambunan and Ferenita, "Alat Pemberi Makan dan Minum Kucing Otomatis Berbasis Modul GSM SIM900A dan Arduino,” Semin. Nas. Inovasi, Teknol. dan Apl. 2018, pp. vii, $1-3,2018$.

[15] E. Susanto, J. T. Elektro, and J. S. Komputer, "Rancang Bangun Alat Pemberi Makan Anjing/Kucing Otomatis dengan Kontrol SMS Dwi Nuri Putri Dharma Mohammad Iqbal," pp. 15-2013, 2013.

[16] Y. Christoforus, I. Zakariah, and A. N. Husnah, "Sistem Kendali Servo Posisi dan Kecepatan Motor dengan Programmable Logic Controler," vol. 1, no. 2, pp. 102-112, 2011.

[17] ardutech, "Starter Kit Arduino Ultrasonic," www.ardutech.com, 2019. https://www.ardutech.com/starter-kit-arduino-ultrasonic/ (accessed Jun. 16, 2020).

[18] ardutec, "Kontrol Servo Motor dengan Arduino," www.ardutech.com, 2019. https://www.ardutech.com/kontrol-servo-motor-dengan-arduino/ (accessed Jun. 16, 2020).

[19] T. Tri Saputro, "Mengenal NodeMCU," embeddednesia.com, 2017. https://embeddednesia.com/v1/tutorial-nodemcu-pertemuan-pertama/ (accessed Jun. 16, 2020).

[20] A. Rahmat, "Cara Mudah Program RTC Module DS1302 Jam Digital Dengan Arduino," kelasrobot.com, 2019. https://kelasrobot.com/cara-mudah-program-rtc-module-ds1302-jam-digitaldengan-arduino/ (accessed Jun. 16, 2020).

[21] T. Widiyaman, "Macam Macam Jenis Keluarga ESP8266," www.warriornux.com, 2017. https://www.warriornux.com/macam-macam-jenis-keluarga-esp8266/ (accessed Jun. 16, 2020).

[22] M. Sholeh, “Aplikasi Telegram Dan 5 Kelebihannya,” kirim.email, 2019. https://kirim.email/aplikasitelegram-dan-5-kelebihannya/ (accessed Jun. 16, 2020).

[23] sinauarduino, "Mengenal Arduino Software (IDE)," www.sinauarduino.com, 2016. https://www.sinauarduino.com/artikel/mengenal-arduino-software-ide/ (accessed Jun. 16, 2020).

[24] sunupradana, "Mengenal Fritzing dan ExpressPCB," sunupradana.info, 2016. https://sunupradana.info/pe/2016/10/15/mengenal-fritzing-dan-expresspcb/ (accessed Jun. 16, 2020). 